ISSN 1112-9867

Available online at

http://www.jfas.info

\title{
INFLUENCE OF FLUORIDE ON THE ELECTROCHEMICAL BEHVIOR OF A NEW SYNTHESIZED Ti-10Ta-2Mo ALLOY FOR BIOMEDICAL APPLICATIONS
}

\author{
L. Sadi Oufella ${ }^{1, *}$, A. Benchettara ${ }^{2}$ \\ ${ }^{1,2}$ Laboratory of Electrochemistry-Corrosion, Metallurgy and Inorganic Chemistry, \\ Faculty of Chemistry, USTHB, El Alia-BP-32, Bab Ezzouar, Algiers 16 079, Algeria
}

Received: 22 March 2016 / Accepted: 22 August 2016 / Published online: 01 September 2016

\begin{abstract}
The aim of the present study is to investigate the corrosion resistance of a new synthesized Ti$10 \mathrm{Ta}-2 \mathrm{Mo}$ in $0.9 \% \mathrm{NaCl}$ solution containing different $\mathrm{NaF}$ concentrations using electrochemical techniques, including open circuit potential, potentiodynamic polarization, cyclic voltammetry and electrochemical impedance spectroscopy.

The results showed that Ti-10Ta-2Mo exhibits a good corrosion resistance in $0.9 \% \mathrm{NaCl}$ as well as in $0.9 \% \mathrm{NaCl}$ containing fluoride and even in acidified $0.9 \% \mathrm{NaCl}$ free of fluoride ion. Very low corrosion current densities and high impedance values were obtained, indicating the passive behavior of the alloy. An active state was observed in acidified $0.9 \% \mathrm{NaCl}$ of $\mathrm{pH} 2$ in the presence of fluoride. The results showed that Ti-10Ta-2Mo is more appropriate than some materials cited in the literature, suggesting its suitability for biomedical applications.
\end{abstract}

Keywords: Ti-10Ta-2Mo; $\mathrm{NaCl}$ 0.9\%; Fluoride; EIS ; Corrosion.

Author Correspondence, e-mail: mellesadioufella@yahoo.fr

doi: http://dx.doi.org/10.4314/jfas.v8i3.5

\section{INTRODUCTION}

Titanium and titanium alloys are the best materials for biomedical and dental applications because of their biocompatibility, excellent mechanical properties and their good corrosion resistance in biological fluids. Their highly chemical stability is due to formation of a very resistant and protective oxide layer on their surface [1-3]. The phenomenon of passivation is a guarantee of their excellent resistance to corrosion in various electrolytic media such as 
$0.9 \% \mathrm{NaCl}$ [4-7], Ringer's solution[8-10], Hank's solution[11, 12], Phosphate buffered saline solution PBS $[13,14]$ and other simulated physiological media.

The contact between the metallic implant and the receiving living tissues is made through the oxide layer on the implant surface, which allows the ossteointegration process $[15,16]$. The chemical properties of the oxide layer play an important role in the biocompatibility of titanium implants and the surrounding tissues and must not break down if the implant is to be successful.

However, titanium oxide films can be destroyed in the oral environment because of its $\mathrm{pH}$ variation, food decomposition, changes in temperature, humidity and oxygen presence. Fluoride is one of the elements that can interact with the metal surface [5, 8, 16-21].

Therapy with fluorides $\left(\mathrm{F}^{-}\right)$is known as the main method to prevent plaque formation and dental caries. Dentifrices, mouthwashes and prophylactic gels can contain from 200 to 20000 ppm $\mathrm{F}^{-}$and can present acidic to neutral character (the $\mathrm{pH}$ is alkaline in the case of inflammations or infections) [22], which can affect the corrosion behavior of titanium alloys biomaterials present in the oral cavity. The effects of fluoride on the corrosion behavior of titanium and its alloys have been presented by several authors [17-21, 23-26]. According to their results, whenever in contact with fluoride solutions, the oxide film undergoes a reaction resulting in the formation of titanium fluoride, titanium oxide fluoride or sodium titanium fluoride on the alloy surface and the corrosion resistance decreases markedly in these fluoride solutions.

According to Strietzel [23], fluoride ions in organic acids with $2.1<\mathrm{pH}<3.8$ can react with Ti surfaces. Frateur et al.[24] observed some pitting on Ti in acidic fluoride media (pH 2.0 and 3.0). Reclaru and Meyer [25] showed that crevice corrosion and pitting occur on Ti alloys in a fluoride containing $\mathrm{NaCl}$ solution with $\mathrm{pH}$ below 3.5. Furthermore, Schiff [26] found pitting of Ti6Al4V alloy in fluoridated acidified saliva ( $\mathrm{pH} 2.5$ ).

On the other hand, among the various types of Ti alloys, the conventional Ti-6Al-4V was one of the first titanium biomaterial introduced in orthopedic implant applications and has achieved a greatest success. Although this alloy is still widely utilized in medicine, some concern has been recently expressed over its use since it appears that small amounts of both vanadium and aluminum, released in the human body, induce possible cytotoxic effect and neurological disorders, respectively [27, 28]. Due to the detrimental effect of Aluminum and vanadium, different titanium alloys containing non toxic elements $(\mathrm{Nb}, \mathrm{Ta}, \mathrm{Mo}, \mathrm{Zr}$ ) known as $\beta$-stabilizer elements, were developed in order to replace Ti-6Al-4V, such as Ti-Ta[29,30], 
Ta-Mo [7, 8, 31, 32]; few works are available in the literature about the mechanical and corrosion behavior of Ti-Ta-Mo ternary alloy [33, 34].

Regarding literature, the corrosion behaviors are related to the concentration of fluoride and the surrounding environment Therefore, the surface reaction on the studied alloy under the existence of fluoride is important, to understand the corrosion of Ti-10Ta-2Mo in oral environment.

\section{MATERIALS AND METHODS}

Ti-10Ta-2Mo substrate used as the working electrode was synthesized from commercially pure $\mathrm{Ti}$, Ta and Mo in an arc-furnace BUHLER MAMI type, under controlled argon atmosphere; ingot with approximately $15 \mathrm{~g}$ was obtained. In order to ensure homogeneity, the sample was turned and remelted another 8 times. The alloy was then homogenized at $1000^{\circ} \mathrm{C}$ for $48 \mathrm{~h}$ then naturally cooled in the furnace to room temperature.

The alloy was characterized by X-ray diffraction using a PHILIPS PW diffractometer using $\mathrm{CuK} \alpha$ radiation (1.54060 $\mathrm{A}^{\circ}$ wave length). The microstructure of the Ti-10Ta-2Mo alloy was analyzed after mirror polishing and etching their surface with a Kroll solution which contains (15mL $\mathrm{HNO} 3,5 \mathrm{~mL} \mathrm{HF}$ and $80 \mathrm{~mL} \mathrm{H}_{2} \mathrm{O}$ ) for approximately 15 s by an optical microscope (ZEISS ICM 405). The microhardness was determined using ZEISS microhardness tester at a load of $200 \mathrm{~g}$ applied for $15 \mathrm{~s}$.

The studied material was embedded into a dental resin after soldering it to a copper wire covered by an insulating matter, giving a geometric area of $0.496 \mathrm{~cm}^{2}$. The active surface undergoes a particular polishing with emery paper of decreasing grit silicate-carbon papers $(240,600,800,1200$ and 2400), watched with distilled water and immediately immersed in the corrosive medium.

The corrosion test electrolyte was $0.9 \% \mathrm{NaCl}$ with a natural $\mathrm{pH} 5.5$ was prepared from analytic grade agents and distilled water. The fluoride species were added to $0.9 \% \mathrm{NaCl}$ solution using $\mathrm{NaF}$ salt to study the influence of fluoride at different concentrations $(0,250$, 500, 750, 1000, 1500 and $9500 \mathrm{ppm}$ ). The $0.9 \% \mathrm{NaCl}$ base solution and $\mathrm{NaF}$ concentrations were chosen based on some reports found in literature [4-6].

In the first part of this study; it was decided to not alter the $\mathrm{pH}$ obtained after $\mathrm{NaF}$ addition in order to avoid the addition of other substances. Indeed; different concentrations of NaF were added to the $\mathrm{NaCl}$ solution and the $\mathrm{pH}$ varies between 5.5 and 6.08. In the second part of this study, the $\mathrm{pH}$ was adjusted to $\mathrm{pH} 2$ using dilute $\mathrm{HCl}$ solution. The solution was naturally 
aerated and the experiments were conducted with stirring. The temperature was maintained at $37^{\circ} \mathrm{C}$ using a thermostatic bath. Prior to polarization experiments or impedance measurements (EIS), the working electrode was immersed in the test solution for one hour.

A conventional three electrode cell of multi necked flask was used in this study, where Ti-10Ta-2Mo was the working electrode. The reference electrode was a saturated calomel electrode (SCE) to which all potentials were referred and a platinum electrode was used as a counter electrode.

Different electrochemical techniques were employed: Open circuit potential measurement, potentiodynamic polarization and cyclic voltammetry were taken with a computer controlled potentiostat PGP201 (Volta lab Radiometer Analytical) piloted by Volta Master 4.0. Potentiodynamic and cyclic voltammetry studies were carried out at a scan rate of $5 \mathrm{mV} / \mathrm{sec}$ from $-600 \mathrm{mV}$ to $+2000 \mathrm{mV}$ vs. SCE with respect to open circuit potencial (OCP) to study the corrosion behaviour.

Electrochemical impedance spectroscopy measurements were performed using the electrochemical interface Solartron 1287 combined with the frequency response analyser Solartron 1260 [7], controlled by the Ecorr/Zplot Software. The frequency was scanned from $100 \mathrm{KHz}$ down to $10 \mathrm{mHz}$ and a $10 \mathrm{mV}$ sinusoidal potential peak to peak was applied.

\section{RESULTS AND DISCUSSION}

\subsection{Microstructure, crystallographic structure and microhardness of Ti-10Ta-2Mo}

The microstructure of the Ti-10Ta-2Mo alloy was analyzed after mirror polishing and etching their surface using a mixture of $15 \mathrm{~mL} \mathrm{HNO}_{3}, 5 \mathrm{~mL} \mathrm{HF}$ and $80 \mathrm{~mL} \mathrm{H}_{2} \mathrm{O}$ for approximately $15 \mathrm{~s}$ (Fig.1).

The microstructure of Ti-10Ta-2Mo reveals the presence of $\alpha$-phase precipitates with a lamellar morphology in a $\beta$-phase matrix, due to the partial transformation of $\beta$-phase(dark area) to $\alpha$-phase (light area) during natural cooling to room temperature in the furnace. Intermediate $\alpha$ 'and $\alpha$ 'phases were also presente according to the DRX pattern. 


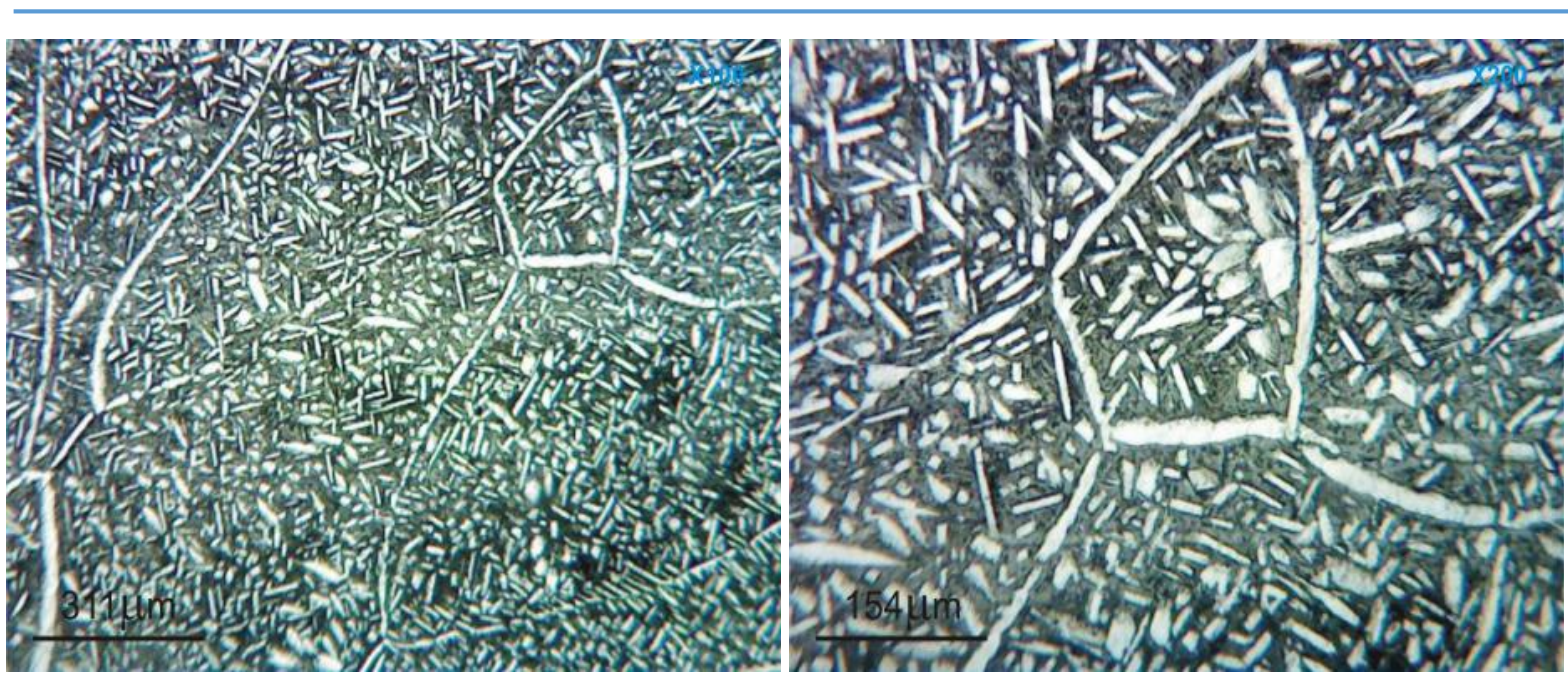

Fig. 1. Optical micrograph of Ti10Ta2Mo alloy: (a) x100, (b) x 200

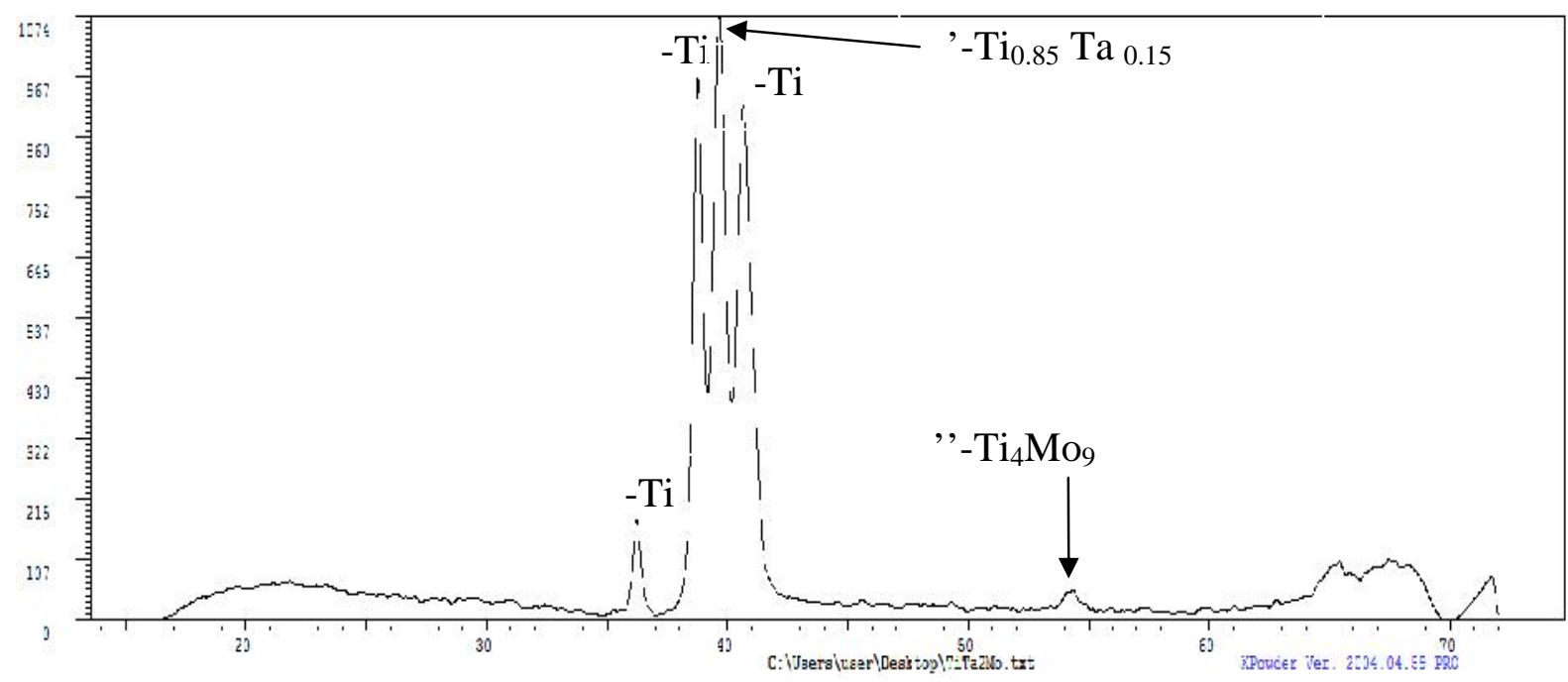

Fig. 2. XRD patern of Ti-10Ta-2Mo homogenized in vacuum at $1000^{\circ} \mathrm{C}$ for $48 \mathrm{~h}$ and natural cooling to room temperature in the furnace.

The alloy was characterized by X-ray diffraction (Fig.2), observed by optical microscopy and found to have a mixture of the body-centred-cubic $\beta$, hexagonal $\alpha$, orthorhombic $\alpha$ ' and tetragonal $\alpha$ " phases. The microhardness of Ti-10Ta-2Mo alloys was found to be $389.5 \pm 5$ $\mathrm{HV}_{0.2}$. 


\subsection{OCP and potentiodynamic polarisation studies of Ti-10Ta-2Mo alloy:}

\subsection{Open circuit potential analysis}

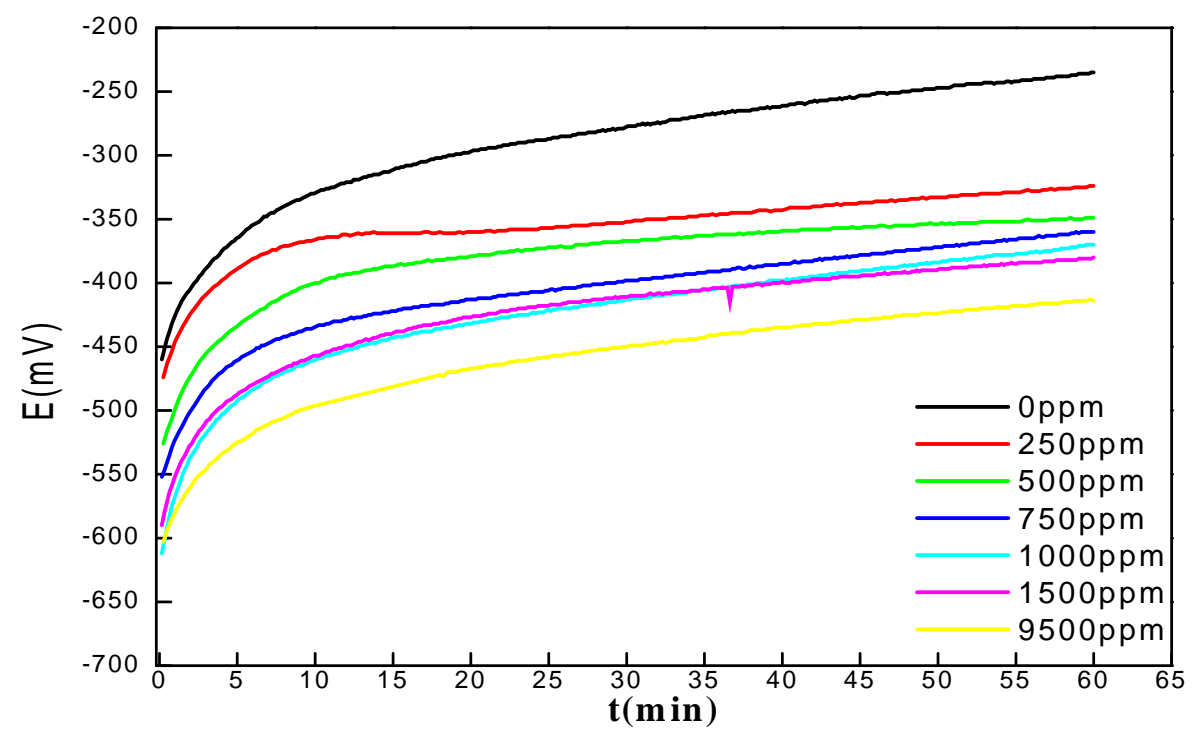

Fig. 3. Open circuit potential vs. time for Ti-10Ta-2Mo in $0.9 \% \mathrm{NaCl}$ in presence of different concentrations of $\mathrm{NaF}$ after $1 \mathrm{~h}$ of immersion.

Fig.3 shows the profil of open-circuit potentials of Ti-10Ta-2Mo as a function of immersion time in aqueous $0.9 \% \mathrm{NaCl}$ containing various $\mathrm{NaF}$ concentrations, at $37^{\circ} \mathrm{C}$. The corrosion potentials increase rapidly with time in the noble direction, attesting the formation and growth of passive film on the surface.

All OCPs values are found in the stability region of $\mathrm{TiO}_{2}$ oxide in $\mathrm{Ti}-\mathrm{H}_{2} \mathrm{O}$ Pourbaix and are recorded in Table. 1 as a function as $\mathrm{F}^{-}$and $\mathrm{HF}$ concentrations calculated using the equilibria constants and mass conservation equation.

The same profils are observed in different physiological medias containing fluoride ion at neutral $\mathrm{pH}$ solution $[10,16]$. The presence of fluoride ions in a solution containing 10000 ppm of $\mathrm{NaF}$ at $\mathrm{pH} 6.75$ does not hinder the formation of a protective layer on the studied titanium alloy using cyclic voltammetry [15]. According to Nakagawa et al [20], in acidic conditions, $30 \mathrm{ppm}$ of HF led to the destruction of the passive film on Ti surface. The amount of formed HF is much lower than $30 \mathrm{ppm}$ as shown in Table. 1; consequently the presence of $\mathrm{F}^{-}$ions in these conditions does not interfere with the formation of a protective layer. 
Table.1 Open circuit potential values as a function of calculated $\mathrm{F}^{-}, \mathrm{HF}$ and $\mathrm{pH}$

\begin{tabular}{ccccc}
\hline$[\mathrm{NaF}] / \mathrm{ppm}$ & measured $\mathrm{pH}$ & {$[\mathrm{HF}] /(\mathrm{ppm})$} & {$\left[\mathrm{F}^{-}\right] /(\mathrm{ppm})$} & $\mathrm{E}(\mathrm{mV})$ \\
\hline 0 & 5.5 & 0 & 0 & $-235,02$ \\
250 & 6.03 & 0.36 & 249.63 & $-324,24$ \\
500 & 6.05 & 0.70 & 499.29 & $-349,14$ \\
750 & 6.04 & 1.08 & 748.91 & $-360,21$ \\
1000 & 6.07 & 1.34 & 99.65 & $-370,36$ \\
1500 & 6.05 & 2.11 & 1497.88 & $-380,18$ \\
9500 & 6.08 & 12.52 & 9487.47 & $-414,25$ \\
\hline
\end{tabular}

\subsubsection{Potentiodynamic polarisation studies}

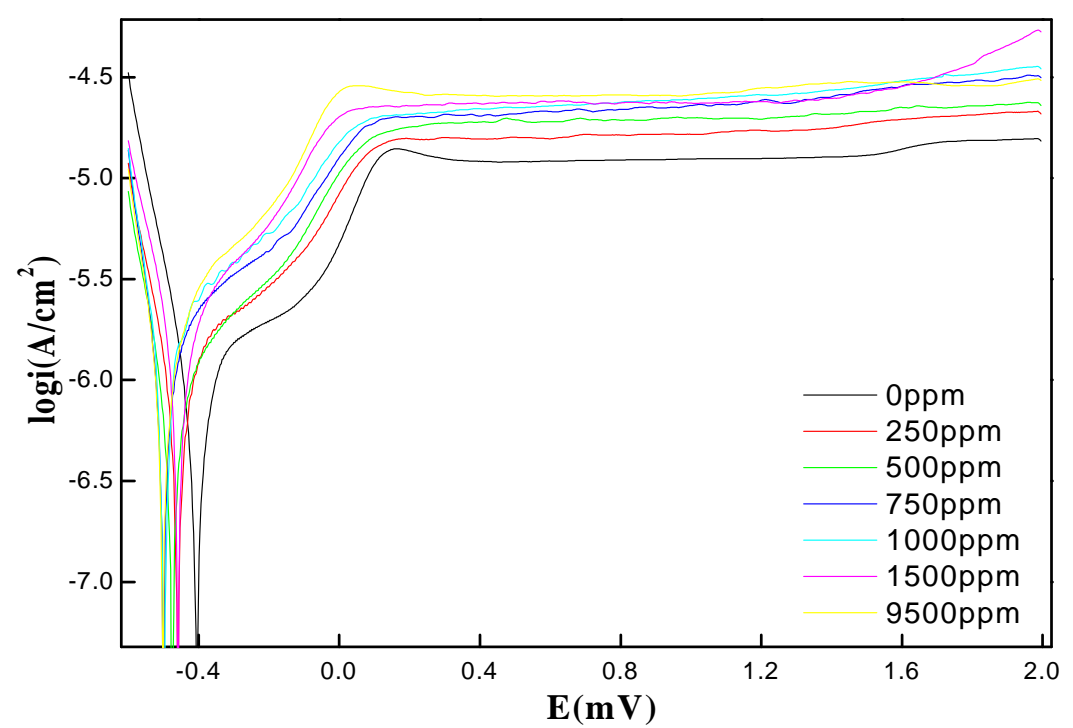

Fig. 4. Potentiodynamic polarization curves for Ti-10Ta-2Mo in $0.9 \% \mathrm{NaCl}$ containing different $\mathrm{NaF}$ concentrations.

Potentiodynamic polarization curves of Ti-10Ta-2Mo in $0.9 \% \mathrm{NaCl}$ solution containing different of fluoride concentrations ions at $37^{\circ} \mathrm{C}$ are illustrated in Fig. 4. For all $\mathrm{NaF}$ concentrations, the alloy reaches a stable passive current densities and no breakdown potential 
is observed in the range potential test (until to $2 \mathrm{~V}$ vs. SCE). This indicates that the passive film formed on the surface of Ti-10Ta-2Mo alloy is very integral and protective.

The corresponding corrosion parameters calculated using Tafel extrapolation method Ti10Ta-2Mo alloy are compiled in Table. 2.

There is a cathodic shift in $\mathrm{E}_{\text {corr }}$ from $-405 \mathrm{mV}$ to $-501.3 \mathrm{mV}$ vs. SCE and an increase in $\mathrm{i}_{\text {corr }}$ from $0.21 \mu \mathrm{A} / \mathrm{cm}^{2}$ to $1.24 \mu \mathrm{A} / \mathrm{cm}^{2}$ with the increase in fluoride ion concentration, indicating their negative effect.

The obtained values of $i_{\text {corr }}$ and $i_{\text {pass }}$ are in order of $10^{-7}$ to $10^{-6} \mathrm{~A} / \mathrm{cm}^{2}$ and are lower than those obtained by some authors $[6,16]$, indicating the good corrosion resistance of the studied alloy. In $0.9 \% \mathrm{NaCl}$ containing $9500 \mathrm{ppm} \mathrm{NaF}$, the $\mathrm{i}_{\text {corr }}$ and $\mathrm{i}_{\text {pass }}$ obtained are respectively about $1.24 \mu \mathrm{A} / \mathrm{cm}^{2}$ and $25.67 \mu \mathrm{A} / \mathrm{cm}^{2}$ but Kumar et al [5] found in their studies that the values of $\mathrm{i}_{\text {corr }}$ and $\mathrm{i}_{\text {pass }}$ for Ti-15Mo (richer in Mo) in the same medium were respectively $2.30 \mathrm{~A} / \mathrm{cm}^{2}$ and $\mathrm{i}_{\text {pass }} 732 \mu \mathrm{A} / \mathrm{cm}^{2}$. Ti-10Ta-2Mo performed well than Ti-15Mo richer in Molybdenum.

Table 2 Electrochemical parameters of $\mathrm{Ti}-10 \mathrm{Ta}-2 \mathrm{Mo}$ in $0.9 \mathrm{NaCl}$ containing different $\mathrm{NaF}$ concentrations obtained from the anodic polarization curves

$\mathrm{NaF} /$

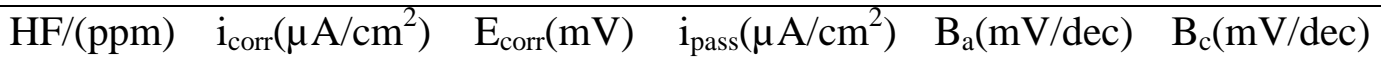

(ppm)

\begin{tabular}{ccccccc}
\hline 0 & 0.00 & 0.21 & -405.02 & 12.26 & 118.91 & -85.31 \\
250 & 0.36 & 0.62 & -459.25 & 16.27 & 90.32 & -84.72 \\
500 & 0.70 & 0.56 & -477.63 & 19.92 & 87.67 & -78.57 \\
750 & 1.08 & 0.55 & -498.19 & 22.82 & 98.52 & -72.02 \\
1000 & 1.34 & 0.66 & -498.51 & 24.67 & 63.73 & -70.13 \\
1500 & 2.11 & 0.72 & -458.92 & 23.78 & 57.22 & -68.22 \\
9500 & 12.52 & 1.24 & -501.36 & 25.76 & 48.95 & -65.15 \\
\hline
\end{tabular}




\subsubsection{Cyclic voltammetry analysis}

Cyclic voltammograms recorded for Ti-10Ta-2Mo2Mo in $0.9 \% \mathrm{NaCl}$ with various $\mathrm{NaF}$ concentrations are shown in Fig.5. They display a region of formation and growth of the anodic oxide in the passive region during the cathodic-anodic potential scan, reaching a current plateau. In the reverse scan, the current density value was reduced rapidly to values close to zero, without reduction of the oxide film formed. The fact that no pitting corrosion occurred in the potential scans in solutions suggests a high resistance to corrosion in the Ti10Ta-2Mo alloy studied at the different $\mathrm{NaF}$ concentrations. The presence of fluoride ions did not prevent the formation of a protective layer at the surface of the alloy because of the small amount of HF formed at all aqueous solutions.

Similar passive behavior characteristic of valve metals was found by [9, 31, 34] but with higher passive current plateau. For example, A. V. Rodrigues [37] found when studying Ti$15 \mathrm{Mo}$ in Ringer solution at $25^{\circ} \mathrm{C}$ that the passive plateau currents are between $300 \mu \mathrm{A} / \mathrm{cm}^{2}$ and $800 \mu \mathrm{A} / \mathrm{cm}^{2}$ which are very higher than those obtained in our study, varying between $12.26 \mu \mathrm{A} / \mathrm{cm}^{2}$ and $25.76 \mu \mathrm{A} / \mathrm{cm}^{2}$, in addition our study was carried out at $37^{\circ} \mathrm{C}$. The Ti-10Ta2Mo shows a better passive behavior than other materials richer in molybdenum.

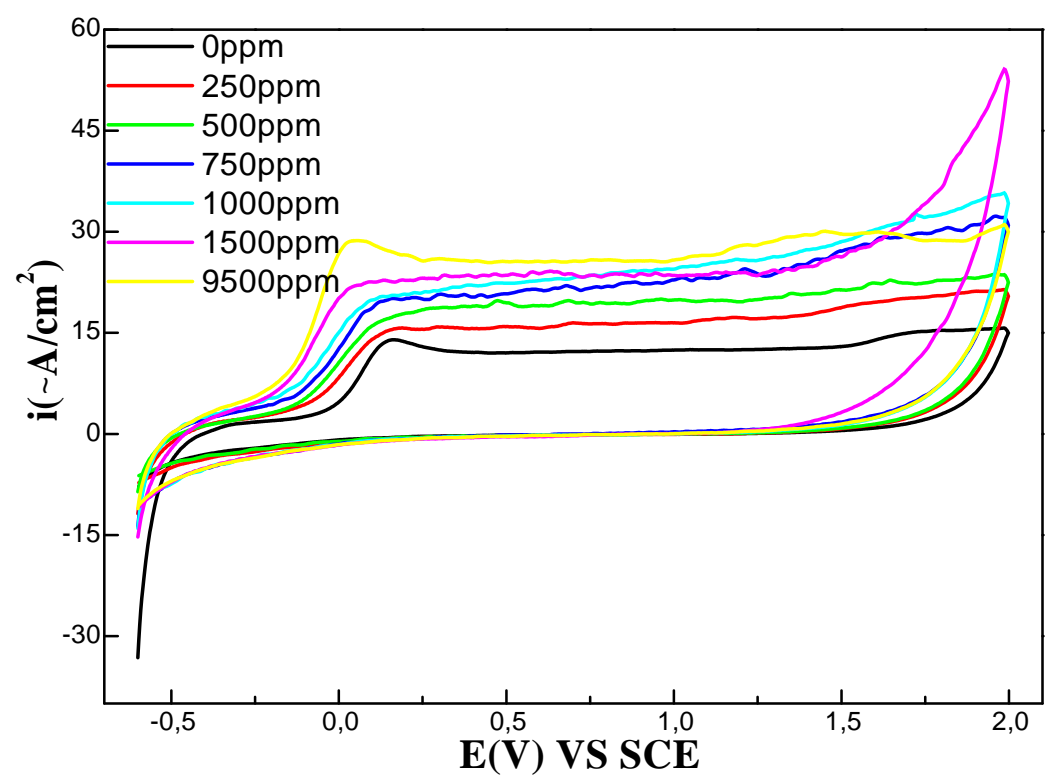

Fig. 5. Cyclic voltammograms for Ti-10Ta-2Mo alloy in $0.9 \% \mathrm{NaCl}$ containing various $\mathrm{NaF}$ concentrations; scan rate $5 \mathrm{mV} / \mathrm{s}$. 


\subsubsection{EIS data analysis}

The EIS measurements of Ti-10Ta-2Mo in $0.9 \% \mathrm{NaCl}$ solution with various concentrations of fluoride ion are presented through Nyquist and Bode phase plots.

The Nyquist diagrams show incomplete semicircles (Fig.6.a), whose diameter decreases slightly with increasing NaF concentration, denoting the dependence of the impedance values on the fluoride ion concentration. The decrease in resistance and increase in capacitance suggests the negative influence of fluoride ions on the corrosion resistance of Ti-10Ta-2Mo alloy and supports the observations made by potentiodynamic polarization studies.

For highly corrosion resistance materials, the corrosion resistance may even reach $10^{5}-10^{6}$ . $\mathrm{cm}^{2}[16,35]$. Therefore, in this study the alloy still maintained good corrosion resistance, though the presence of fluoride led to a decrease in resistance. In our study, the obtained resistance $\mathrm{R}_{\mathrm{ct}}$ values are between $17.47 \mathrm{k} \quad . \mathrm{cm}^{2}$ and $134.85 \mathrm{~K} \quad . \mathrm{cm}^{2}$ and are high enough to admit the good performance of the studied alloy. In addition, these values are higher than those obtained by some authors [5, 16]. S. Kumar [5] found only $65.8 \mathrm{~K} . \mathrm{cm}^{2}$ for Ti-15Mo richer in Molybdenum in $0.9 \mathrm{NaCl}$ without fluoride, in our study $\mathrm{R}_{\mathrm{b}}$ is about $134.85 \mathrm{~K} . \mathrm{cm}^{2}$; in $0.9 \% \mathrm{NaCl}$ containing 9500ppm of fluoride, S. Kumar found about $6.64 \mathrm{~K} \mathrm{.cm}$ and we found in our study $17.47 \mathrm{~K} \quad \mathrm{~cm}^{2}$. Also, A.M. Al-Mayouf et al [16] found lower value of $\mathrm{R}_{\mathrm{b}}$ for Ti6Al4V and Ti-30Cu-10Ag studied in artificial saliva at $\mathrm{pH} 7.2$ without and with fluoride presence. The alloy Ti-10Ta-2Mo performs better compared to some alloys cited in the literature, confirming its suitability for biomedical applications.

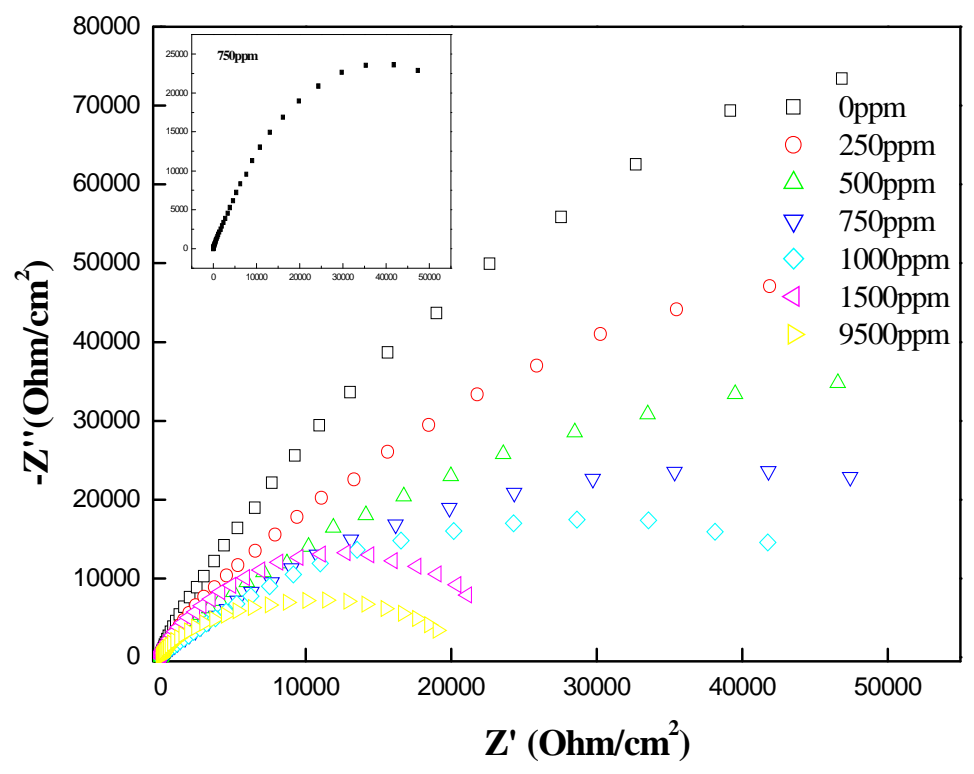


Fig.6 (a). Nyquist plots of $\mathrm{Ti}-10 \mathrm{Ta}-2 \mathrm{Mo}$ alloy in natural $0.9 \% \mathrm{NaCl}$ without and with varying $\mathrm{NaF}$ concentrations .

The Bode phase angle plots presented in Fig.6 (b) show two peaks revealing the involvement of two relaxation time constants, attributed to the bi-layered oxide surface consisting of a porous outer layer and a barrier inner layer $[17,18]$. The phase angle maximum approaching $90^{\circ}$ at intermediate frequencies is typical for a passive surface indicating good corrosion resistance of the studied alloy.

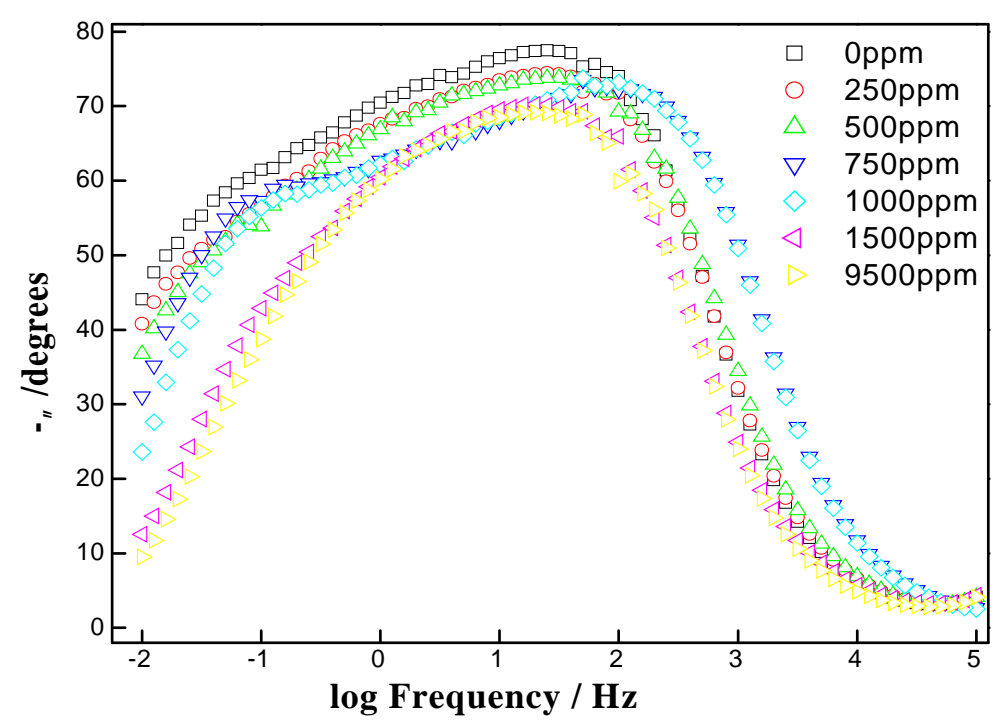

Fig.6 (b). Bode phase angle plots for $\mathrm{Ti}-10 \mathrm{Ta}-2 \mathrm{Mo}$ alloy in $0.9 \% \mathrm{NaCl}$ without and with varying $\mathrm{NaF}$ concentrations.

An equivalent electrical circuit (ECC) consisted of $\operatorname{Rs}\left(C_{1} R_{1}\right)\left(C_{d l} R_{c t}\right)$ was used to model the impedance spectra data (Fig.7).$R_{\mathrm{S}}$ is the solution resistance, $\mathrm{C}_{1}$ and $\mathrm{R}_{1}$ are the capacitance and resistance of the oxide film, respectively. $\mathrm{C}_{\mathrm{dl}}$ is the capacitance of the double layer and $R_{\mathrm{ct}}$ is the resistance charge transfer. This EEC was already proposed by different authors to fit the impedance data for titanium and titanium alloys [3, 4, 17, 18, 19, 22 36, 37]. The different electrochemical parameters derived from the impedance spectra simulated by ZView software are recorded in Table.3.

The layer at the interface cannot be considered as an ideal capacitor and the constant phase element (CPE) was often used as a substitute for the ideal capacitor. The impedance of CPE is given by:

$Z_{C P E}=\left[C(j \omega)^{n}\right]^{-1}$ 
Where, $\mathrm{C}$ is the capacitance, $(\mathrm{j} \omega)$ is the complex variable for sinusoidal perturbations with $w=2 \pi f$, and $n$ is related to non-uniform current distribution due to surface roughness or inhomogeneity [21].

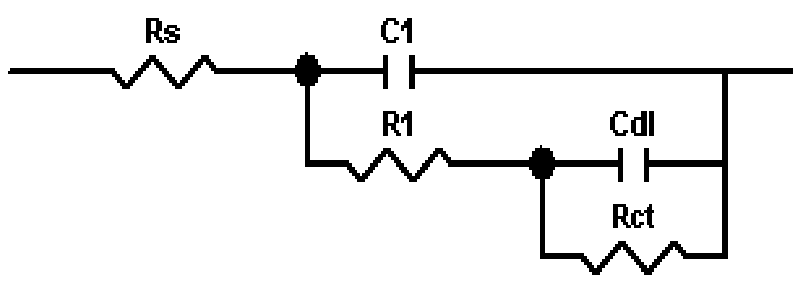

Fig. 7. The equivalent circuit used for the modeling of the impedance spectra for Ti-10Ta$2 \mathrm{Mo}$ alloy in $0.9 \% \mathrm{NaCl}$ without and with fluoride presence

Table. 3 Electrochemical parameters derived from the impedance spectra in $0.9 \% \mathrm{NaCl}$ containing different $\mathrm{NaF}$ concentrations.

\begin{tabular}{cccccccc}
\hline$/$ & $\mathrm{R}_{\mathrm{s}}\left(. \mathrm{cm}^{2}\right)$ & $\mathrm{C}_{1}\left(\mathrm{~F}_{\mathrm{cm}}{ }^{-2}\right)$ & $\mathrm{n}_{1}$ & $\mathrm{R}_{1}\left(. \mathrm{cm}^{2}\right)$ & $\mathrm{C}_{\mathrm{dl}}\left(\mathrm{F}_{\mathrm{cm}} \mathrm{cm}^{-2}\right)$ & $\mathrm{n}_{2}$ & $\mathrm{R}_{\mathrm{ct}}\left(\quad . \mathrm{cm}^{2}\right)$ \\
\hline $0 \mathrm{ppm}$ & 18.93 & $1.17 .10^{-5}$ & 0.89 & 5795 & $2.83 .10^{-5}$ & 0.90 & 134850 \\
$250 \mathrm{ppm}$ & 13.68 & $5.16 .10^{-5}$ & 0.81 & 4254 & $3.88 .10^{-5}$ & 0.86 & 88680 \\
$500 \mathrm{ppm}$ & 10.82 & $5.89 .10^{-5}$ & 0.79 & 3134 & $4.71 .10^{-5}$ & 0.84 & 68100 \\
$750 \mathrm{ppm}$ & 5.51 & $5.79 .10^{-5}$ & 0.80 & 1475 & $7.13 .10^{-5}$ & 0.85 & 53047 \\
$1000 \mathrm{ppm}$ & 5.34 & $5.92 .10^{-5}$ & 0.75 & 1666 & $10.23 .10^{-5}$ & 0.83 & 45091 \\
$1500 \mathrm{ppm}$ & 17.97 & $6.20 .10^{-5}$ & 0.77 & 8805 & $12.53 .10^{-5}$ & 0.82 & 29896 \\
$9500 \mathrm{ppm}$ & 11.4 & $6.56 .10^{-5}$ & 0.71 & 3983 & $14.52 .10^{-5}$ & 0.83 & 17478 \\
\hline
\end{tabular}

3.3 OCP measurements and potentiodynamic polarisation studies of Ti-10Ta-2Mo alloy at pH 2

\subsubsection{Open circuit potential analysis at pH 2}




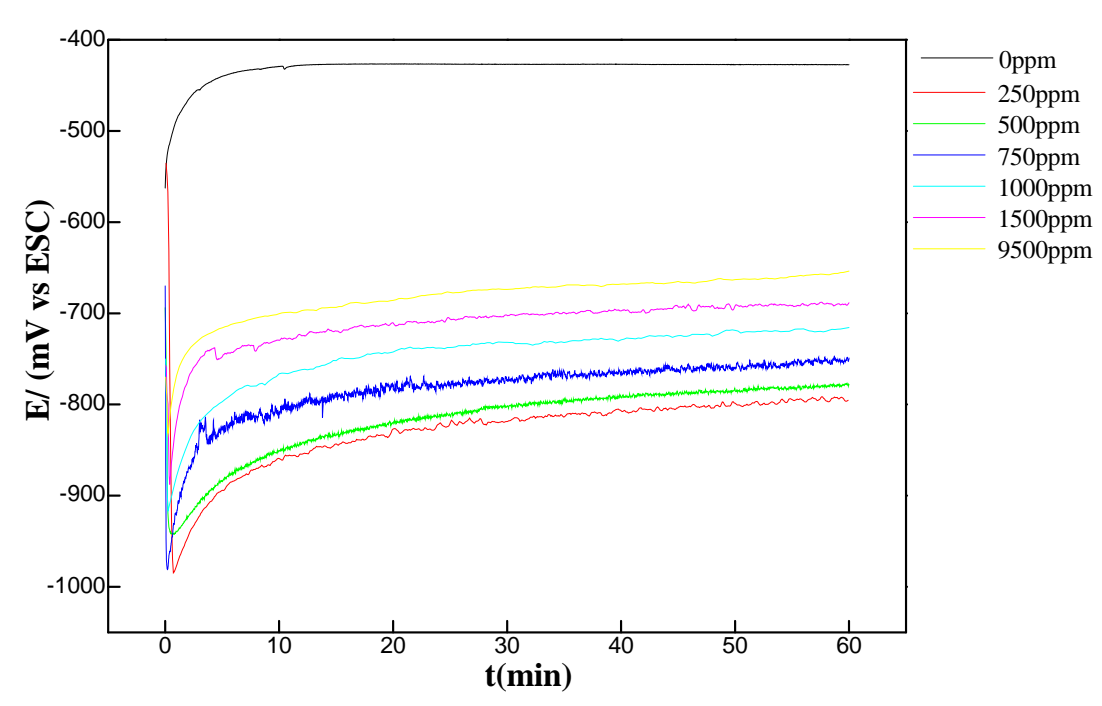

Fig . 8. Variation of open circuit potential with exposure time for Ti-10Ta-2Mo in acidified $0.9 \% \mathrm{NaCl}$, containing various $\mathrm{NaF}$ concentrations ( 0 to $9500 \mathrm{ppm})$ at $\mathrm{pH} 2$.

Fig. 8 shows the variation of OCP for Ti-10Ta-2Mo in $0.9 \% \mathrm{NaCl}$ without and with different fluoride concentrations at $\mathrm{pH} 2$.

For $0.9 \% \mathrm{NaCl}$ of $\mathrm{pH} 2$ without fluoride, the OCP shifts on the noble direction, attesting the development of passive films on the studied alloy. In $0.9 \% \mathrm{NaCl}$ of $\mathrm{pH} 2$ containing fluoride, the OCPs drop sharply to very negative values and then start to increase and reach a constant value. Similar behavior was observed by other authors $[38,8,16]$, but with more negative values of OCP.

The open circuit potential obtained in our study in $0.9 \% \mathrm{NaCl}$ containing fluoride varies between $-428 \mathrm{mV}$ and $-796 \mathrm{mV}$ after $1 \mathrm{~h}$ of immersion, values which are more noble but those obtained by A. Robin [8] for CP-Ti, Ti-5Nb-13Zr, Ti-13Nb-13Zr and Ti-20Nb-13Zr in Ringer's solution of pH 3 containing $1000 \mathrm{ppm} \mathrm{F}$, the values are between $-881 \mathrm{mV}$ and $964 \mathrm{mV}$ respectively. The OCP values found by A.M Al-Mayouf [16] for Ti and Ti-6Al-4V in artificial saliva of $\mathrm{pH} 3.0$ containing only $0.01 \mathrm{M}$ fluoride are about $-952 \mathrm{MmV}$ and $-924 \mathrm{mV}$, respectively.

Such a decrease in potential denotes the active behavior of the studied alloy [32, 39, 40]. At $\mathrm{pH} 2, \mathrm{~F}^{-}$ions are hydrolyzed and the HF amount formed increases with increasing $\mathrm{NaF}$ added to $0.9 \% \mathrm{NaCl}$ solution. Table. 4 reports the calculated concentration of and $\mathrm{HF}, \mathrm{F}^{-}$for $\mathrm{pH}=2$ at different fluoride ions and the corresponding open circuit potential after $1 \mathrm{Sec}, 1 \mathrm{~min}$ and $1 \mathrm{~h}$. It is clear that the concentration of HF formed increases with increasing $\mathrm{NaF}$ added to the base 
solution $0.9 \% \mathrm{NaCl}$ at $\mathrm{pH} 2$, this lead to the destruction of the passive layer. Visual inspection confirms the macroscopic corrosion and the roughness of the alloy surface.

Table.4 Open circuit potential values after $1 \mathrm{sec}, 1 \mathrm{~min}$ and $60 \mathrm{~min}$ of immersion at $\mathrm{pH} 2$ obtained from the OCP measurement

\begin{tabular}{cccccc}
\hline$[\mathrm{NaF}] \mathrm{ppm}$ & $\mathrm{HF} / \mathrm{ppm}$ & $\mathrm{F}-/ \mathrm{ppm}$ & $\mathrm{E}(\mathrm{mV})$ after & $\mathrm{E}(\mathrm{mV})$ after & $\mathrm{E}(\mathrm{mV})$ after \\
& & & $1 \mathrm{sec}$ & $1 \mathrm{~min}$ & $1 \mathrm{H}$ \\
\hline 0 & 0.00 & 0.00 & -562.08 & -486.01 & -428.31 \\
250 & 235.18 & 14.82 & -534.25 & -985.21 & -796.23 \\
500 & 470.36 & 29.63 & -794.32 & -943.12 & -778.41 \\
750 & 705.55 & 44.45 & -670.63 & -980.14 & -752.14 \\
1000 & 940.73 & 59.27 & -749.12 & -917.41 & -715.12 \\
1500 & 1411.1 & 88.90 & -355.47 & -886.23 & -690.21 \\
9500 & 8936.97 & 563.03 & -796.21 & -836.31 & -657.08 \\
\hline
\end{tabular}

\subsubsection{Potentiodynamic polarisation studies at $\mathbf{p H} 2$}

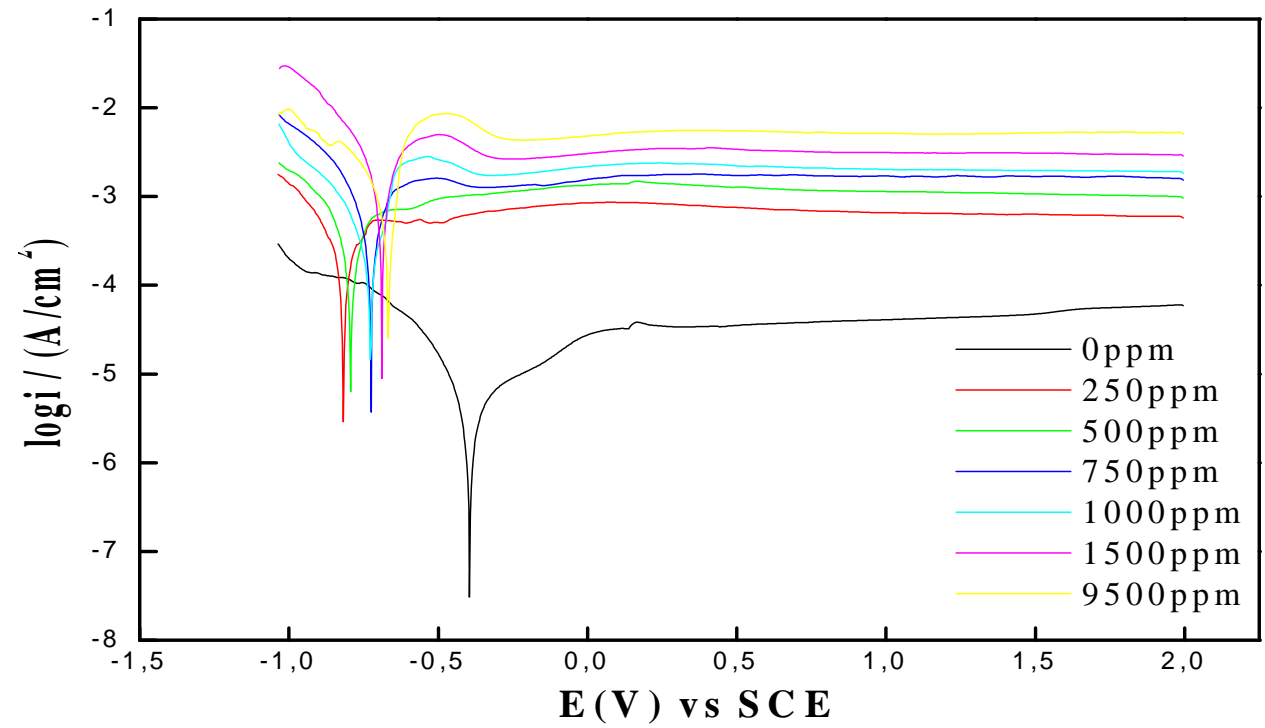

Fig.9. Potentiodynamic polarization curves for Ti-10Ta-2Mo alloy in acidified $0.9 \% \mathrm{NaCl}$ with varying $\mathrm{NaF}$ concentrations at $\mathrm{pH} 2$ 
The anodic polarization curves of Ti-10Ta-2Mo in $0.9 \% \mathrm{NaCl}$ solution of $\mathrm{pH} \mathrm{2,} \mathrm{containing}$ various $\mathrm{NaF}$ concentrations are presented in Fig. 9. These curves present a noticeable activepassive transition, which supports the spontaneous active behavior of Ti-10Ta-2Mo at OCP under these conditions. Similar results were obtained for Ti, Ti-6Al-7Nb and Ti-6Al-4V alloys in $0.1 \% \mathrm{NaF}$ [38] and for CP-Ti, Ti-5Nb-13Zr, Ti-13Nb-13Zr and Ti-20Nb-13Zr in Ringer's solution of $\mathrm{pH} 2$ containing $1000 \mathrm{ppm}$ of fluorides [8].

The active behavior was attributed to the presence of hydrofluoric acid HF which dissolves the oxide film on the surface of the alloy via the formation of Ti-F compounds such as $\mathrm{TiF}_{3}$, $\mathrm{TiF}_{4}$, and $\mathrm{TiOF}_{2}$ according to the following reactions [20]:

$$
\begin{aligned}
& \mathrm{TiO}_{2}+2 \mathrm{HF} \rightarrow \mathrm{TiOF}_{2}+\mathrm{H}_{2} \mathrm{O} \\
& \mathrm{TiO}_{2}+4 \mathrm{HF} \rightarrow \mathrm{TiF}_{4}+2 \mathrm{H}_{2} \mathrm{O} \\
& \mathrm{Ti}_{2} \mathrm{O}_{3}+6 \mathrm{HF} \rightarrow 2 \mathrm{TiF}_{3}+3 \mathrm{H}_{2} \mathrm{O}
\end{aligned}
$$

Table.5 reports the different electrochemical parameters as a function as the formed HF concentration. The corrosion current densities $i_{\text {corr }}$ and passive current densities $i_{\text {pass }}$ increased nearly 3 and 2 order of magnitude respectively in $0.9 \% \mathrm{NaCl}$ containing fluoride ions at $\mathrm{pH} 2$, when compared to the values measured for $0.9 \% \mathrm{NaCl}$ without fluoride ions. The same tendency was found in several studies [8, 16, 20, 21, 38, 40].

Table. 5 Electrochemical parameters of Ti-10Ta-2Mo in $0.9 \% \mathrm{NaCl}$ containing different $\mathrm{NaF}$ concentrations at $\mathrm{pH} 2$ obtained from the anodic polarization curves

\begin{tabular}{ccccccc}
\hline $\begin{array}{c}{[\mathrm{NaF}]} \\
(\mathrm{ppm})\end{array}$ & $\begin{array}{c}\mathrm{HF} \\
(\mathrm{ppm})\end{array}$ & $\mathrm{E}_{\mathrm{cor}} / \mathrm{mV}$ & $\mathrm{I}_{\mathrm{cor}} / \mu \mathrm{A} / \mathrm{cm}^{2}$ & $\mathrm{i}_{\text {pass }}\left(\mu \mathrm{A} / \mathrm{cm}^{2}\right)$ & $\mathrm{B}_{\mathrm{a}}(\mathrm{mV} / \mathrm{dec})$ & $\begin{array}{c}\mathrm{B}_{\mathrm{c}} \\
(\mathrm{mV} / \mathrm{dec})\end{array}$ \\
\hline 0 & 0.00 & -391 & 0.72 & 25.23 & 109.42 & -89.22 \\
250 & 235.18 & -720 & 170.7 & 676.82 & 117.504 & -94.51 \\
500 & 470.36 & -792 & 240.3 & 1096.47 & 125.32 & -98.13 \\
750 & 705.55 & -723 & 333.1 & 1737.80 & 140.41 & -104.51 \\
1000 & 940.73 & -725 & 689.5 & 2045.73 & 147.93 & -105.12 \\
1500 & 1411.1 & -686 & 738.2 & 3162.27 & 150.11 & -107.94 \\
\hline
\end{tabular}




$\begin{array}{lllllll}9500 & 8936.97 . & -664 & 836.4 & 5128.13 & 156.32 & -113.32\end{array}$

\subsubsection{EIS data analysis at $\mathrm{pH} 2$}

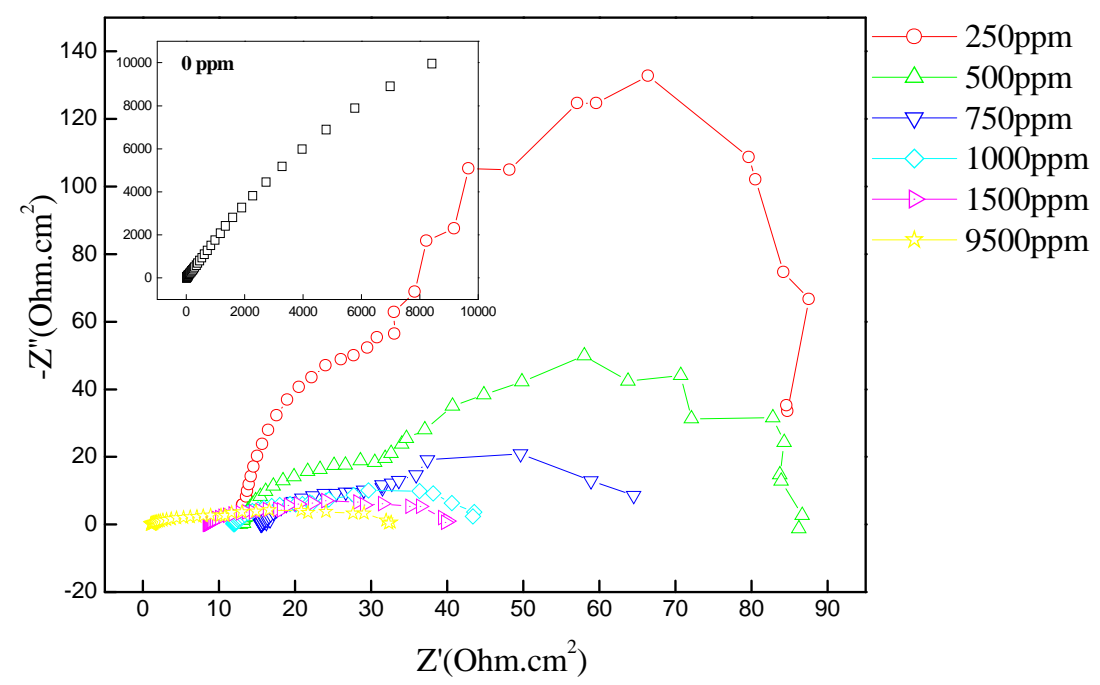

Fig.10 (a). Nyquist diagrams of $\mathrm{Ti}-10 \mathrm{Ta}-2 \mathrm{Mo}$ in $0.9 \% \mathrm{NaCl}$ without and with varying $\mathrm{NaF}$ concentrations at $37^{\circ} \mathrm{C}$ at $\mathrm{pH} 2$.

The impedance spectra of Ti-10Ta-2Mo alloy in $0.9 \% \mathrm{NaCl}$ containing different fluoride ion concentrations are presented as Nyquist and bode phase angle plots and are shown in Fig.10 (a) and Fig.10 (b) respectively. The Nyquist plots without fluoride ions exhibit a small and flattened semicircle, followed by another incomplete semicircle with high impedance value. In the presence of fluoride ions, Nyquist plots are constituted of two defined semicircles characterized by very small diameters which decrease drastically as the fluoride concentration increase, indicating the great reduction in corrosion resistance. Two relaxation time constants are clearly indicated by two peaks on the phase angle plots denoting the presence of two layers at the surface (Fig.10 (b)).

The impedance data were fitted using the equivalent electrical circuit shown in Fig.7 and the different electrochemical parameters derived from the impedance spectra simulated by ZView software were recorded in Table.6. 


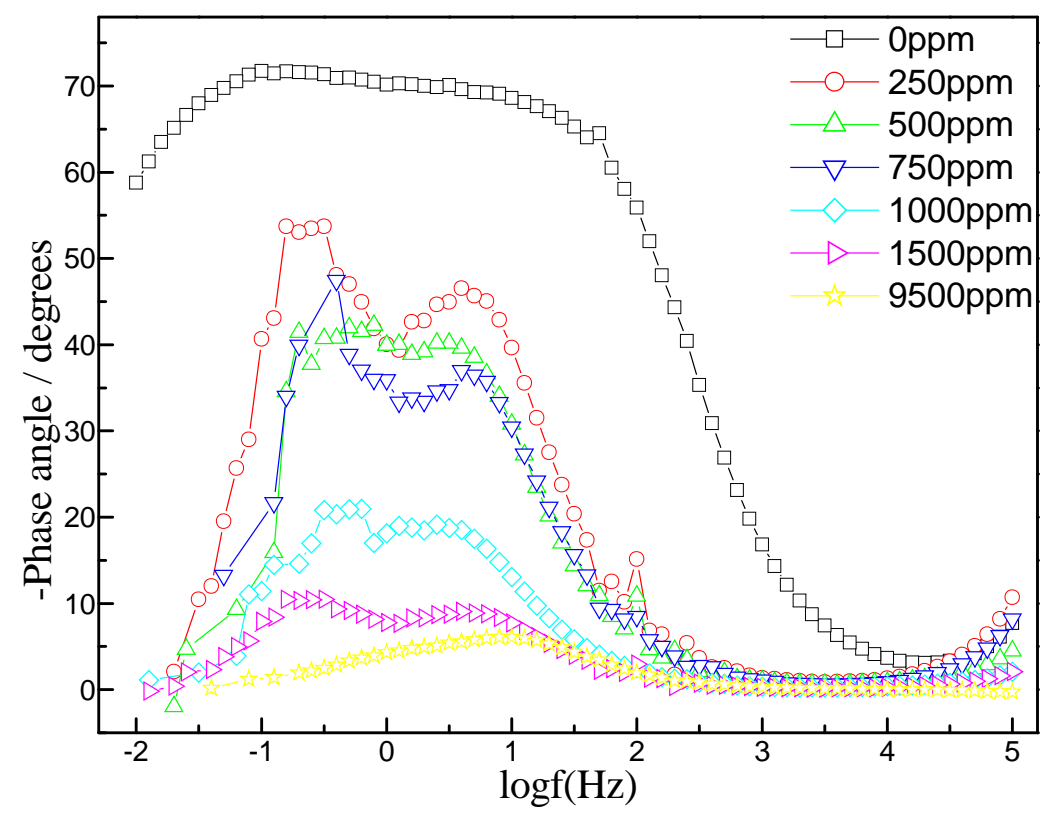

Fig.10 (b). Bode phase diagrams of $\mathrm{Ti}-10 \mathrm{Ta}-2 \mathrm{Mo}$ in $0.9 \% \mathrm{NaCl}$ without and with varying $\mathrm{NaF}$ concentrations at $\mathrm{pH} 2$.

The corrosion resistance of the alloy diminished significantly at $\mathrm{pH} 2$ when the concentration of fluoride ions increases. Very low values of the charge transfer resistance are found and it indicates that it does not act as a barrier layer [41]. The presence of high concentration of fluoride destroyed the two layers affecting severely their corrosion resistance [42]. An identical tendency is obtained by A. Robin et al [21] but with more feeble values of charge transfer resistance.

The charge transfer obtained for Ti-10Ta-2Mo in $0.9 \% \mathrm{NaCl}$ containing $1000 \mathrm{ppm}$ of fluoride is $18.40 \mathrm{~cm} 2$ (Table.6), which is higher than those obtained for Ti-6Al-4Vand Ti-23Ta alloys in saliva of pH 2 containing 1000 ppm Fluoride [21]. The charge transfer resistances are only about 2.727 and 9.995 .cm2, respectively. This comparison indicates the good performance of the studied Ti-10Ta-2Mo alloy. 
Table. 6 Electrochemical parameters derived from the impedance spectra in $0.9 \% \mathrm{NaCl}$ containing different $\mathrm{NaF}$ concentrations at $\mathrm{pH} 2$

\begin{tabular}{|c|c|c|c|c|c|c|c|}
\hline I & $\mathrm{R}_{\mathrm{s}}\left(. \mathrm{cm}^{2}\right)$ & $\begin{array}{c}\mathrm{C}_{1} \\
\left(\mathrm{~F} \cdot \mathrm{cm}^{-2}\right)\end{array}$ & $\mathrm{n}_{\mathrm{p}}$ & $\mathrm{R}_{1}\left(. \mathrm{cm}^{2}\right)$ & $\begin{array}{c}\mathrm{C}_{\mathrm{dl}} \\
\left(\mathrm{F} \cdot \mathrm{cm}^{-2}\right)\end{array}$ & $\mathrm{n}_{\mathrm{b}}$ & $\mathrm{R}_{\mathrm{ct}}\left(. \mathrm{cm}^{2}\right)$ \\
\hline Oppm & 12.21 & 0.00024 & 0.806 & 378.30 & 0.00026 & 0.95 & 78205 \\
\hline $250 \mathrm{ppm}$ & 12.88 & 0.0038 & 0.854 & 30.39 & 0.021 & 0.90 & 43.62 \\
\hline $500 \mathrm{ppm}$ & 12.50 & 0.0039 & 0.875 & 23.15 & 0.015 & 0.91 & 26.50 \\
\hline 750ppm & 12.01 & 0.0044 & 0.875 & 16.21 & 0.026 & 0.92 & 24.68 \\
\hline $1000 \mathrm{ppm}$ & 12.91 & 0.0038 & 0.854 & 11.47 & 0.026 & 0.93 & 18.40 \\
\hline $1500 \mathrm{ppm}$ & 9.87 & 0.0025 & 0.883 & 07.21 & 0.033 & 0.95 & 06.47 \\
\hline $9500 \mathrm{ppm}$ & 1.39 & 0.0011 & 0.898 & 4.20 & 0.055 & 0.98 & 3.50 \\
\hline
\end{tabular}

\section{CONCLUSION}

In this work, a new titanium alloy Ti-10Ta-2Mo was synthesized using the melting process in an arc furnace, under atmosphere of argon. The influence of fluoride ion concentration and $\mathrm{pH}$ on the electrochemical and corrosion behaviors of Ti-10Ta-2Mo in $0.9 \% \mathrm{NaCl}$ was investigated utilizing electrochemical techniques. The main conclusions are summarized as follows:

- In natural $0.9 \% \mathrm{NaCl}$ solution containing fluoride, the $\mathrm{HF}$ concentration formed was low and not sufficient to dissolves the passive film that naturally exists at the surface of the alloy. The increase in fluoride ions concentration decreases slightly the corrosion resistance of the alloy but does not interfere with the formation of a protective layer at the surface.

- Very low corrosion current densities and passive current densities (in the order of $10^{-6}$ $\mathrm{A} / \mathrm{cm}^{2}$ ) were obtained from the polarization curves, which is indicative of higher stability of the passive films in $0.9 \% \mathrm{NaCl}$ with and without fluoride ions in natural $0.9 \% \mathrm{NaCl}$ solution. High impedance values (in order of $10^{6} \mathrm{~cm}^{2}$ ) were obtained corroborating with the results obtained in the OCP, potentiodynamique polarization and cyclic voltammetry techniques. 
- In acidified $0.9 \% \mathrm{NaCl}$ not containing fluoride, a passive behavior is observed was observed for Ti-10Ta-2Mo, traduced by very low current densities and high impedance values.

- In acidified $0.9 \% \mathrm{NaCl}$ solution of $\mathrm{pH} 2$ containing various concentrations of fluoride, the corrosion resistance of Ti-10Ta-2Mo decreased markedly in comparison with that in a solution not containing fluoride which is due to the interaction of the alloy with the important content of $\mathrm{HF}$ formed at $\mathrm{pH} 2$ resulting to the progressive deterioration of surface oxide film.

- At $\mathrm{pH} 2$, increased fluoride increased $\mathrm{i}_{\text {corr }}$ from 1.59 to $836.4 \mu \mathrm{A} / \mathrm{cm}^{2}$ and shifted $\mathrm{E}_{\text {corr }}$ from -391 to $-664 \mathrm{mV}$, moreover, very low impedance $\left(10^{1} \mathrm{~cm}^{2}\right)$ values were obtained which confirm the active state of the Ti-10Ta-2Mo under these conditions attributed to the presence of high HF concentration.

- The comparison of our results to other studies attested that Ti-10Ta-2Mo performed well than some other materials cited in the literature and is acceptable for biomedical applications.

\section{REFERENCES}

[1] Huang YZ, Blackwood DJ. Characterization of titanium oxide film grown in $0.9 \% \mathrm{NaCl}$ at different sweep rates. Electrochim. Acta., 2005, 51, (1099-1107)

[2] Fadl-allah Sahar A, Mohsen Q. Characterization of native and anodic oxide films formed on commercial pure titanium using electrochemical properties and morphology techniques. Appl. Surf. Sci., 2010, 256, (5849-5855)

[3] Pan. J, Thierry. D, Leygraf. C, Electrochemical impedance spectroscopy study of the passive oxide film on titanium for implant application. Electrochim. Acta., 1996, 41, (11431153)

[4] Xie FX, He XB, Cao SL, Lu X, Qu XH. Structural characterization and electrochemical behavior of a laser-sintered porous Ti-10Mo alloy. Corros. Sci., 2013, 67, (217-224)

[5] Kumar S, Sankara Narayanan TSN. Corrosion behaviour of Ti-15Mo alloy for dental implant applications. J. Dent., 2008, 36, (500 - 507)

[6] Kumar S, Sankara Narayanan TSN. Influence of fluoride ion on the electrochemical behavior of $\beta$-Ti alloy for dental implant application. Corros. Sci., 2010, 52 , (1721 -1727) 
[7] Wang BL, Zheng YF, Zhao LC. Electrochemical corrosion behavior of biomedical Ti$22 \mathrm{Nb}$ and Ti-22Nb-6Zr alloys in saline medium. Mater. Corros., 2009, 60, (788-794)

[8] Robin A, Carvalho OAS. Influence of $\mathrm{pH}$ and Fluoride Species on the Corrosion Behavior of Ti-xNb-13Zr Alloys in Ringer's Solution. Adv. Mater. Sci. Eng., 2013, (2013), doi: http://dx.doi.org/10.1155/2013/434975

[9] Oliveira NTC, Ferreira EA, Durate LT, Bggio SR, Rocha-Filho RC, Bocchi N. Corrosion resistance of anodic oxides on the Ti-50Zr and Ti-13-Nb-13-Zr alloys. Electrochim. Acta., 2006, 51, (2068-2075)

[10] Robin A, Carvalho OAS, Schneider SG, Schneider S. Corrosion behavior of Ti-xNb13Zr alloys in Ringer's solution. Mater. Corros. 2008., 59, (929-933)

[11] De Assis SL., Wolynec S, Costa I. Corrosion characterization of titanium alloys by electrochemical techniques. Electrochim. Acta., 2006, 51, (1815-1819)

[12] Assis SL, Costa I. Electrochemical evaluation of Ti-13Nb-13Zr, Ti-6Al-4V and Ti-6Al$7 \mathrm{Nb}$ alloys for biomedical application by long-term immersion tests. Mater. Corros., 2007, 58, (329-333)

[13] Khan MA, Williams RL, Williams DF. In-vitro corrosion and wear of titanium alloys in the biological environment. Biomater., 1996, 17, (2117-2126)

[14] Khan MA, Williams RL, Williams DF. The corrosion behavior of Ti-6Al-4V, Ti-6Al$7 \mathrm{Nb}$ and $\mathrm{Ti}-13 \mathrm{Nb}-13 \mathrm{Zr}$ in protein solutions. Biomater., 1999, 20, (631-637)

[15] Toumelin-chemia F, Rouelle, F, Burdairon G. Corrosive properties of fluoride-containing odontologic gels against titanium. J. Dent., 1996, 24, (109-115)

[16] Al-Mayouf AM, Al-Swayih AA, Al-Mobarak NA, Al-Jabab AS. Corrosion behavior of a new titanium alloy for dental implant applications in fluoride media. Mater. Chem. Phys., 2004, 86, (320-329)

[17] Souza JCM, Barbosa SL, Ariza E, Celis JP, Rocha LA. Simultaneous degradation by corrosion and wear of titanium in artificial saliva containing fluorides. Wear., 2012, 292-293, (82-88)

[18] Huang HH. Electrochemical impedance spectroscopy study of strained titanium in fluoride media. Electrochim. Acta., 2002,47, (2311-2318)

[19] Souza JCM., Barbosa SL, Ariza E, Henriques M, Teughels W, Ponthiaux P, Celis JP , Rocha LA. How do titanium and Ti6Al4V corrode in fluoridated medium as found in the oral cavity? An in vitro study. Mater. Sci. Eng. C., 2015, 47, (384-393)

[20] Nakagawa M, Matsuya S, Shiraishi T, Ohta M. Effect of fluoride concentration and $\mathrm{pH}$ on corrosion behavior of titanium for dental use. J. Dent. Res., 1999, 78(9), (1568 - 1572) 
[21] Robin A, Meirelis JP. Influence of fluoride concentration and $\mathrm{pH}$ on corrosion behavior of Ti-6Al-4V and Ti-23Ta alloys in artificial saliva. Mater. Corros., 2007, 58, (173-180)

[22] Calderon Moreno JM, Vasilescu E, Drob P, Osiceanu P, Vasilescu C, Drob SI, Popa M. Surface and electrochemical characterization of a new ternary titanium based alloy behaviour in electrolytes of varying pH. Corros. Sci., 2013, 77, (52-63)

[23] Streitzel R, Hösch A, Kalbfleisch H, Buch D. In vitro corrosion of titanium, Biomater., 1998, 19(16),(1495-1499)

[24] Frateur I, Lattarin S, Musiani M, Tribollet BJ. Electrodissolution of Ti and p-Si in acidic fluoride media: formation ratio of oxide layers from electrochemical impedance spectroscopy. J.Electroanal. Chem., 2000, 482(2), (02- 210)

[25] Reclaru L, Meyer JM. Effects of fluorides on titanium and other dental alloys in dentistry. Biomater., 1998, 19(1-3),(85-92)

[26] Schiff N, Grosgogeat B, Lissac M, Dalard F. Influence of fluoride content and pH on the corrosion resistance of titanium and its alloys. Biomater.,1995, 23(9),(1995-2002)

[27] Lavos-Valereto IC, Wolynec S, Deboni MCZ, Konig Jr B. In-vitro and in-vivo biocompatibility testing of $\mathrm{Ti}-6 \mathrm{Al}-7 \mathrm{Nb}$ alloy with and without plasma-sprayed hydroxyapatite coatings. J. Biomed. Mater. Res., 2001, 58,(727-33)

[28] Brama M, Rhodes N, Hunt J, Ricci A, Teghil R, Migliaccio S and al. Effect of titanium carbide coating on the ossteointegration response in vitro and in vivo. Biomater., 2007, 28,(595-608)

[29] Zhou YL, Niinomi M, Akahori T, Fukui H, Toda H. Corrosion resistance and biocompatibility of Ti-Ta alloys for biomedical applications. Mater. Sci. Eng. A., 2005, 398, (28-36)

[30] Mareci D, Chelariu R, Gordin DM, Ungureanu G, Gloriant T. Comparative corrosion study of Ti-Ta alloys for dental applications. Acta Biomater., 2009, 5, (3625-3639)

[31] Oliveira NTC, Aleixo G, Caramb R, Guastaldi AC. Development of Ti-Mo alloys for biomedical applications: Microstructure and electrochemical characterization. Mater Sci. Eng. A., 2007, 452-453, (727-731)

[32] Oliveira NTC, Guastaldi AC. Electrochemical stability and corrosion resistance of TiMo alloys for biomedical applications. Acta Biomater., 2009, 5, (399-405)

[33] Delvat E, Gordin DM, Gloriant T, Duval JL, Nagel MD. .Microstructure, mechanical properties and cytocompatibility of stable beta Ti-Mo-Ta sintered alloys. J. Mech. Behav. Biomed. Mat., 2008, 1(4), (345-351) 
[34] Gordin DM, Gloriant T, Nemtoi Gh, Chelariu R, Aelenei N, Guillou A, Ansel. Synthesis, structure and electrochemical behavior of a beta Ti-12Mo-5Ta alloy as new biomaterial. Mater. Lett., 2005, 59(23), (2936 - 2941)

[35] D.A. Jones, Principles and Prevention of Corrosion, Prentice-Hall, $2^{\text {nd }}$ edition, New Jersey, 1996, pp. 143-167.

[36] Dalmau A, Guinon Pina V, Devesa F, Amigo V, Igual Munoz A. Electrochemical behavior of near-beta titanium biomedical alloys in phosphate buffer saline solution. Mater. Sci. Eng. C., 2015, 48, (55-62)

[37] Rodrigues AV, Oliveira NTC, Dos Santos ML, Guastaldi AC. Electrochemical behavior and corrosion resistance of $\mathrm{Ti}-15 \mathrm{Mo}$ alloy in naturally-aerated solutions, containing chloride and fluoride ions. J. Mat. Sci: Mater. Med., 2015, doi: 10.1007/s10856-014-5323-0

[38] Nakagawa M, Matsuya S, Udoh K. Corrosion behavior of pure titanium and titanium alloys in fluoride-containing solutions. Dent. Mater. J., 2001, 20, (305-14)

[39] Nakagawa $M$, Matsuya $S$, Udoh $K$, Effect of fluoride and dissolved oxygen concentrations on the corrosion behavior of pure titanium and titanium alloys. Dent. Mater. J., 2002, 21, (83-92)

[40] Nakagawa M, Matono Y, Matsuya S, Udoh K, Ishikawa K. The effect of Pt and Pd alloying additions on the corrosion behavior of titanium in fluoride containing environments. Biomater., 2005, 26, (2239-2246)

[41] Cheng TP, Lee JT and Tsai WT. Passivation of titanium in molybdate containing sulphuric acid solution. Electrochim. Acta., 1991, 36, (2069-2076)

[42] Huang HH, Lee TH. Electrochemical impedance spectroscopy study of Ti-6Al-4V alloy in artificial saliva with fluoride and/or bovine albumin. Dent. Mater., 2005, 21, (749-755)

\section{How to cite this article:}

Sadi Oufella L, Benchettara A. Influence of fluoride on the electrochemical behvior of a new synthesized ti-10ta-2mo alloy for biomedical applications. J. Fundam. Appl. Sci., 2016, 8(3), 731-752. 